\title{
VIOLENT BORDERS: REFUGEES AND THE RIGHT TO MOVE
}

\section{Reece Jones: Violent Borders : Refugees and the Right to Move. Verso, 2 I 2 str. London, 2017.}

Vpliv političnih meja na gibanje ljudi ima pomembno mesto $\mathrm{v}$ (politično)geografskem proučevanju selitev. Dinamičnost obeh pojavov, ki je rezultat neprestanega spreminjanja političnega, družbenega, gospodarskega in nenazadnje tudi naravnega prostora, postavlja pred raziskovalce vedno nove izzive in vprašanja. $\mathrm{V}$ zadnjih dveh desetletjih smo bili priče krepitvi obsega mednarodnih selitev na globalni ravni. Le-ta je v številnih predelih sveta sprožila močno spolitizirano razpravo o priseljevanju ter okrepila negativen odziv javnosti do priseljencev in priseljevanja. »Selitvene vojne« (Hyndman, 2005) - razpravo o tem komu dovoliti vstop v državo in komu ne - se najbolj vidno manifestirajo v krepitvi nadzora na mejah ter zaostrovanju priseljevalne politike (Mountz, 2009).

Ameriški geograf Reece Jones se skozi celotno akademsko kariero ukvarja z mejami, problematiko militarizacije meja in njenih posledic (Jones, 2011, 2012, 2015; Jones, Johnson, 2016). Knjiga Violent borders : refugees and the right to move, izdana pri založbi Verso leta 2016, predstavlja pregled avtorjevega raziskovalnega dela na omenjenem področju. Osrednja tema knjige je nasilje, ki ga povzročajo meje. Avtor trdi, da so meje inherentno nasilne, ker vzpodbujajo sistematično nasilje nad ljudmi in okoljem. Na tem mestu velja poudariti, da je podnaslov knjige rahlo zavajajoč. Knjiga namreč ne govori o vplivu meja na selitve beguncev oziroma prisilnih migrantov, ampak o migrantih na splošno. Podnaslov lahko razumemo kot marketinško potezo založbe, saj je knjiga izšla v času t. i. Evropske begunske krize.

V uvodnem poglavju Jones opozarja, da meje producirajo različne oblike nasilja. Prva, najbolj vidna oblika nasilja je neposredno fizično nasilje mejnih organov in mejne infrastrukture nad migranti. Uporaba moči oziroma sile, zaradi katere se poveča možnost poškodb, smrti ali pomanjkanja, predstavlja drugo. Tretjo predstavlja grožnja z nasiljem, ki je povezana z omejevanjem dostopa do različnih resursov in ozemlja. Četrto predstavlja nasilje, ki ga meje povzročajo ekonomskemu blagostanju ljudi. Nasilje, ki ga meje povzročajo okolju, predstavlja zadnjo obliko.

Struktura knjige sledi omenjeni taksonomiji. Prvi del knjige, sestavljen iz prvih treh poglavij, je posvečen prvima dvema oblikama nasilja. V njem avtor opozarja na naraščajočo militarizacijo meja, zaradi katere so migranti vse bolj izpostavljeni neposrednemu 
in posrednemu fizičnemu nasilju. Gradnja fizičnih preprek, povečan nadzor, uporaba novih metod in tehnik nadzora pogosto silijo migrante $\mathrm{v}$ uporabo nevarnejših tranzitnih poti. Posledično smo bili v zadnjem desetletju priče skokoviti rasti števila smrtnih žrtev med migranti.

Prvo poglavje v središče postavlja meje v Evropi oziroma Evropski uniji. Avtor opozarja na dvojno naravo meja v Evropski uniji. Medtem, ko se nadzor na notranjih mejah odpravlja, se na zunanjih mejah nadzor vse bolj zaostruje, kar vodi k vse večjemu nasilju. Avtor ugotavlja, da meje v Evropski uniji niso izginile, ampak so se le prestavile na nove lokacije.

V središču drugega poglavja je vse večja militarizacija meja med Združenimi državami Amerike in Mehiko (Jones militarizacijo opredeli kot prodiranje vojaške strategije, kulture, tehnologije in mišljenja v delo mejne policije). Le-ta je pripomogla k oblikovanju specifičnega diskurza o selitvah in nadzoru meja. V njem so migranti predstavljeni kot ključna varnostna grožnja, mejni nadzor pa kot novo bojišče oziroma vojno območje, na katerem se bojujejo ZDA.

Nasilje na mejah pa ni značilno le za Evropsko unijo in ZDA. Militarizacija meja in z njo povezana rast nasilja je prisotna povsod po svetu. V tretjem poglavju so predstavljeni primeri iz Indije, Bangladeša, Izraela in Avstralije. Po mnenju avtorja utrjevanje in militarizacija meja predstavljata reartikulacijo in širitev moči suverenih držav (str. 68).

Četrto poglavje predstavlja nekakšen uvod v drugi del knjige. V njem avtor ugotavlja, da je omejevanje gibanja revnih značilno za različne režime in tipe oblasti, saj je ena od osnovnih funkcij države nadzirati gibanje ljudi ter nadzorovati in upravljati dostop do ozemlja in resursov/bogastva. Oblikovanje sistema državljanstev in osebnih dokumentov, s katerimi se nadzira in omejuje selitve v sodobnem svetu, tako predstavlja eno od praks, katerih namen je omejevati gibanja revnih ter nadzorovati dostop do resursov.

Omejevanju dostopa do resursov je posvečeno peto poglavje. V njem avtor podrobneje predstavi proces množičnega ograjevanja in lastninjenja skupnih vaških zemljišč v Veliki Britaniji v 17. stoletju ter oblikovanje vestfalskega sistema suverenih držav. Oba procesa sta povečala zmožnost držav, da nadzirajo dostop do ozemlja, resursov in priložnosti. V nadaljevanju avtor ugotavlja, da se omejevanje dostopa do resursov nadaljuje tudi danes. Pri tem izpostavlja Konvencijo Združenih narodov o pomorskem mednarodnem pravu (ang. United Nations Convention on the Law of the Sea), s katero je bil v večji meri olastninjen še zadnji skupni prostor na Zemlji - svetovna morja.

$\mathrm{V}$ šestem poglavju avtor razkriva dvojne standarde, ki so značilni za proces globalizacije ter idejo proste trgovine. Za globaliziran svet, ki ga ustvarjajo prostotrgovinski sporazumi, je značilen prost pretok kapitala in dobrin, ne pa tudi prost pretok ljudi/delovne sile. V njem se namenoma ohranjajo meje, ki ustvarjajo razlike v prihodkih, okoljskih predpisih, davkih in delovnih pogojih, ki koristijo bogatim in škodujejo revnim.

V sedmem poglavju so predstavljeni negativni vplivi meja na okolje. Najprej so predstavljeni neposredni negativni učinki na okolje, do katerih prihaja zaradi utrjevanja in militarizacije meja, v nadaljevanju pa se avtor osredotoči na globalno raven in klimatske spremembe, ki smo jim priča. Pri tem opozarja, kako velik negativen vpliv na okolje ima ekskluzivna pravica suverenih držav do neomejene rabe resursov na lastnem teritoriju. 
Medtem ko je raba resursov omejena z državnimi mejami, so učinki klimatskih sprememb, do katerih prihaja zaradi pretirane rabe resursov, globalni in pogosto najbolj prizadenejo območja, ki najmanj prispevajo k izkoriščanju le-teh. Po mnenju avtorja je Organizacija združenih narodov nesposobna rešiti problem klimatskih sprememb, ker deluje na principu suverenosti držav, ki strogo prepoveduje vmešavanje drugih držav v notranje zadeve posameznih članic.

Jones v sedmih poglavij pokaže, kako obstoječ sistem meja in z njim povezano nasilje odločilno prispevata k ohranjanju razlik med bolj in manj razvitimi predeli sveta oziroma te razlike še povečujeta. Obstoj meja omogoča izbrancem, da vzdržujejo svoj privilegiran položaj ter še naprej akumulirajo bogastvo, hkrati pa večini Zemljanov onemogoča prosto gibanje ter dostop do resursov.

Po njegovem je odprava meja nujna, če želimo oblikovati svet, v katerem se lahko vsi prosto gibajo in imajo enak dostop do virov in priložnosti, hkrati pa lahko v njem učinkovito rešujemo globalne okoljske probleme. Prvi korak k temu cilju predstavlja odprtje meje in vsem Zemljanom omogočiti svobodo gibanja. Oblikovanje globalnih predpisov in standardov glede zaščite delavcev predstavlja drugi korak, tretjega pa sprejetje globalnih standardov pri varovanju okolja ter uveljavitev omejitev pri razpolaganju s privatno lastnino.

Knjiga Violent borders obravnava zelo aktualno tematiko. Globalni selitveni tokovi in odziv držav nanje so v zadnjem desetletju pritegnili pozornost številnih raziskovalcev. Posledično ima bralec, ki ga tematika zanima, na voljo širok nabor znanstvene literature. Jonesovo dela izstopa zaradi treh razlogov. Prvič, zaradi pristopa k obravnavani tematiki. Avtor se pri obravnavi nasilja političnih meja v sodobnem svetu ne omejuje le na vzpon novih, vse bolj smrtonosnih varnostnih praks - omenjeni vidik nasilnosti meja je v literaturi pogosto izpostavljen. Zanimivo je njegovo razmišljanje o vlogi meja pri ohranjanju neenakosti v svetu ter nezmožnosti reševanja globalnih okoljskih problemov, ki je predstavljeno v drugem delu knjige. Avtorju sicer lahko očitamo, da argumenti, s katerimi zagovarja omenjeni tezi, niso tako prepričljivi kot tisti, s katerimi zagovarja svobodo gibanja. Razloge za to lahko iščemo v dejstvu, da se je v tem delu nekoliko oddaljil od svojega raziskovalnega področja, zato ugotovitev ni mogel podpreti z rezultati terenskega dela in raziskav. Kljub temu pa drugi del knjige odpira pomembna vprašanja, katerih reševanje bo pomembno vplivalo na prihodnost sveta.

Argumentacija stališč je drug razlog, zakaj Jonesova knjiga izstopa. Violent borders ni suhoparno znanstveno delo, v katerem bi avtor v težko razumljivem jeziku predstavil svoje poglede. Jonesova lahko razumljiva ter hkrati visoko strokovna argumentacija omogoča tudi manj podučenim bralcem, da brez težav sledijo njegovemu razmišljanju. Pri tem je ključno, da avtor teorijo podkrepi s številnimi primeri iz svojega večletnega terenskega dela ter različnimi zgodovinskimi primeri.

Tretji razlog za izpostavitev Jonesove knjige pa so rešitve, ki nam jih avtor ponuja. V svetu, zaznamovanem z naraščajočim nacionalizmom, ksenofobijo in rasizmom, kjer so migranti neprestano portretirani kot nevarnost in kjer je militarizacija meja predstavljena kot edina možnost, nam avtor ponuja diametralno nasprotno rešitev. Ideja o odpravi meja se zdi na prvi pogled utopična in neizvedljiva. Pri tem se moramo vprašati: Zakaj je temu 
tako? Zakaj nam je ideja o svetu brez meja in držav tako nepredstavljiva? Jones razloge za to išče v globoki vtkanosti držav, meja in omejenega dostopa do resursov v našo kulturo in mišljenje. Hkrati nas opozarja, da je enako v preteklosti veljalo za suženjstvo, kolonializem, apartheid ... pa so bili kljub temu odpravljeni.

Knjiga Violent borders : refugees and the right to move predstavlja obvezno branje za vse, ki se raziskovalno ukvarjajo s problematiko selitev in migracijskih politik. Zanimiva pa je tudi za širšo javnost. Tako imenovana begunska kriza je v Sloveniji, podobno kot drugod v Evropi, sprožila burno razpravo o selitvah in migrantih. V javnem diskurzu je prevladalo stališče, da begunci/migranti predstavljajo grožnjo, ki jo je treba ustaviti z okrepljenim nadzorom nad mejami in omejitvijo priseljevanja. Knjiga Violent borders nam z umestitvijo selitev v širši kontekst ponuja drugačen pogled in predlaga popolnoma drugačen pristop $\mathrm{k}$ reševanju problema.

Pred kratkim je izšel tudi slovenski prevod knjige z naslovom Nasilne meje: begunci in pravica do gibanja. Knjigo v prevodu Ane Kralj in s spremno besedo Mojce Pajnik je izdala založba *cf. v rdeči zbirki.

\section{Literatura in viri}

Hyndman, J., 2005. Migration wars: Refuge or refusal? Geoforum, 1 spec. iss., 36, str. 3-6.

Jones, R., 2011. Border security, 9/11 and the enclosure of civilisation. The Geographical Journal, 3, 177, str. 213-217. DOI: 10.1111/j.1475-4959.2011.00416.x.

Jones, R., 2012. Border walls: Security and the war on terror in the United States, India and Israel. Zed Books.

Jones, R., 2015. The Mediterranean: International region and deadly border. Nordia geographical publications, 4, 44, str. 37-42.

Jones, R., Johnson, C., 2016. Border militarisation and the re-articulation of sovereignty. Transactions of the Institute of British geographers, 2, 41, str. 187-200. DOI: 10.1111/ tran.12115.

Mountz, A., 2009. Migration. V: Gallaher, C., Dahlman, C. T., Gilmartin, M., Mountz, A., Shirlow, P. (ur.). Key concepts in political geography. SAGE Publications, str. 174-184. 